\title{
Democracy on the move? Bogotá's urban transport strategies and the access to the city
}

\author{
Giovanni Vecchio* (1)
}

\begin{abstract}
Introduction: Everyday urban mobility is fundamental to access the opportunities offered by cities, something required to accomplish one's own aims and guarantee participation in social life. Nonetheless, it is difficult to guarantee significant individual opportunities by fighting mobility-related social exclusion, especially in Global South cities characterized by scarce provision of mobility services and wide presence of urban poverty.

Case study: The city of Bogotá has addressed the issues of mobility-related social exclusion by creating a large bus rapid transit system, called TransMilenio. Introduced in 2000, the public transport network was intended to provide a wider access to urban opportunities to a wider share of the urban population.

Discussion and evaluation: The TransMilenio has been an influential example due to its ability in addressing the messed mobility of a typical Global South metropolis and in promoting an intervention that requires less financial resources in comparison to other, traditional infrastructures. However, its results appear as partial when discussing the contribution of TransMilenio to urban access, as well as the economic and political implications of implementing such system.

Conclusions: While relevant is the alternative form of intervention promoted by TransMilenio, as well as its courage in addressing the apparently untamable mobility of a metropolis like Bogotá, similar strategies in the future should pay more attention to the issues of access - intended both as the possibility to make use of this public transport system, both in terms of reaching urban opportunities.
\end{abstract}

Keywords: Urban mobility, Accessibility, Social inclusion, Bus rapid transit, TransMilenio, Bogotá, Urban South

\section{Background}

The access to opportunities allowed by everyday urban mobility is fundamental to take part in a society built around the assumption of high mobility. Mobility is required in order to reach opportunities such as goods, services, places and people, allowing persons to be part of those relational networks that may matter to them (Cass et al. 2005). It contributes to the pursuit of personal life strategies and to the accomplishment of individual preferences, while different personal, social and spatial features define diverse personal capacities for everyday

*Correspondence: giovanni.vecchio@polimi.it

Department of Architecture and Urban Studies, Politecnico di Milano, Via Bonardi 3, 20133 Milan, Italy mobility (Kaufmann et al. 2004; Larsen et al. 2006; Urry 2007; Cresswell 2010; Kellerman 2012). These differences may result in potential inequalities, leading to a social disadvantage that manifests itself in various forms of exclusion (Kenyon et al. 2002; Litman 2010; Lucas 2012; Schwanen et al. 2015; Lucas et al. 2016a): in fact, people may be prevented "from participating in the economic, political and social life of the community because of reduced accessibility to opportunities, services and social networks, due in whole or part to insufficient mobility" (Kenyon et al. 2002, pp. 210-211).

Everyday mobility is often presented as a crucial field of action to contrast social exclusion (Lucas 2012; Preston and Rajé 2007) and consequently enhance quality of life (Stanley and Vella-Brodrick 2009). However, research on 
mobility-related social exclusion is often characterized by the lack of clear conceptualizations (Lucas et al. 2016b) as well as by a tendency to overlook "the broader implication of a comprehensive transport policy" (Beyazit 2011, p. 130), so that its influence on planning practice is quite limited. Despite awareness on the differentiated effects that the same infrastructural interventions may have on different groups and populations (e.g. Booth et al. 2000), infrastructures are often designed without taking much into account their splintering effects on people and spaces (Graham and Marvin 2001). Instead, a recent wave of mobility plans-in Europe and in the United Stateshas explicitly addressed mobility-related social issues, even if with different (and often critical) approaches and results (Arsenio et al. 2016; Manaugh et al. 2015), and despite a chronic lack of reliable data in this sense (Jaramillo et al. 2012).

Guaranteeing the everyday access to relevant urban opportunities is even a more pressing challenge for urban settings in the Global South, where "access to employment is critical to fight against poverty, and (..) the availability of good transport infrastructure and services is a basis on which this access can be achieved" (World Bank 2002, p. 28). Lack of access may result also in high rates of urban criminality (Gouverneur 2016, p. 77). Furthermore, access is central in the paradigm for sustainable urban mobility promoted by United Nations Human Settlements Programme (2013), which in its analysis of the state of mobility in different countries of the world assumes that "the prevailing challenges of urban mobility are consequences of the preoccupation with the means of mobility rather than its end-which is the realization of accessibility" (United Nations Human Settlements Programme 2013, p. 1). Improving accessibility is thus crucial for increasing the possibility that each person has to participate in urban life. However, the suggested courses of action privilege the provision of high-capacity public transport systems, accompanied by the institutions and governance schemes required for their implementation; in fact, in Global South cities the pressing issues of urban poverty are often accompanied by a lack of resources required to develop such systems.

In its proposals for guarantying access in Global South settings, UN Habitat focuses on three typologies of public transport systems: metro, light rail and bus rapid transit (BRT). This last option is presented as a privileged solution, due to the possibility to guarantee a reliable public transport service by using relatively smaller amounts of funds. To promote BRT systems, the case of Bogotá (Colombia) is often presented as the most successful reference model, due to the effectiveness of its service and to its significant role within a wider strategy of social inclusion promoted in the city. The system, called
TransMilenio, started operations in 2000: after almost two decades of service, it is possible to critically reexamine the experience of Bogotá, and to assess its effectiveness in guarantying a wider access to urban opportunities to a wider share of its urban population. In fact, Bogotá allows a 'Southern' perspective (Yiftachel 2006) on a typically Western institutional discourse on mobility, according to which interventions on transport systems are required to enhance personal opportunities because "obstructions to mobility networks are seen as an affront on liberty and freedom of citizens" (Doughty and Murray 2016, p. 308). To do so, the paper intends to briefly explain the relevance of Bogotás experience, define a framework for assessing its urban transport strategies in relation to improving access to urban opportunities, and finally provide an analysis of the results that TransMilenio has achieved.

\section{Case study}

The history of Bogotá as an interesting example of transport planning starts in the Nineties. Like many other cities in the Global South, in the second half of the Twentieth century Bogotá experiences a fast and disordered growth. Different are the reasons that in Colombia push people towards cities: a lack of economic opportunities and significant services in rural areas (Robinson 2016); the attempt to improve one's own economic condition, in a country characterized by the highest economic inequality in South America (the Gini index of Colombia is 55.9: see Lopez-Calva et al. 2015; Székely and Mendoza 2015); the decades-long conflict that see guerrilla movements, paramilitary groups, narcotraffic cartels and the State continuously fighting between each other (Ballvé 2012; Salcedo Fidalgo 2015). This migratory process fosters the growth of informal settlements, which can offer affordable housing, easy access to basic provisions and proximity to some job occasions (Torres Tovar 2009). At the same time, the unplanned origin of these neighborhoods-often illegal or semilegal-offers some answers to basic needs such as housing and basic provisions, but does not allow the public interventions that guarantee equally basic services such as electricity, water or transport, nor they provide a good access to urban opportunities such as services and jobs. Consequently, the areas that respond to the basic needs of a relevant share of the urban population also generate needs that are more difficult to address, in comparison with the formal areas of the city. In the case of Bogotá, such issues are worsened by the location of the informal settlements, spread in the southern part of the city, characterized by higher elevation and high distances from the city center; moreover, these areas host the highest densities of inhabitants and are home to the worst-off groups (Figs. 1 and 2). 


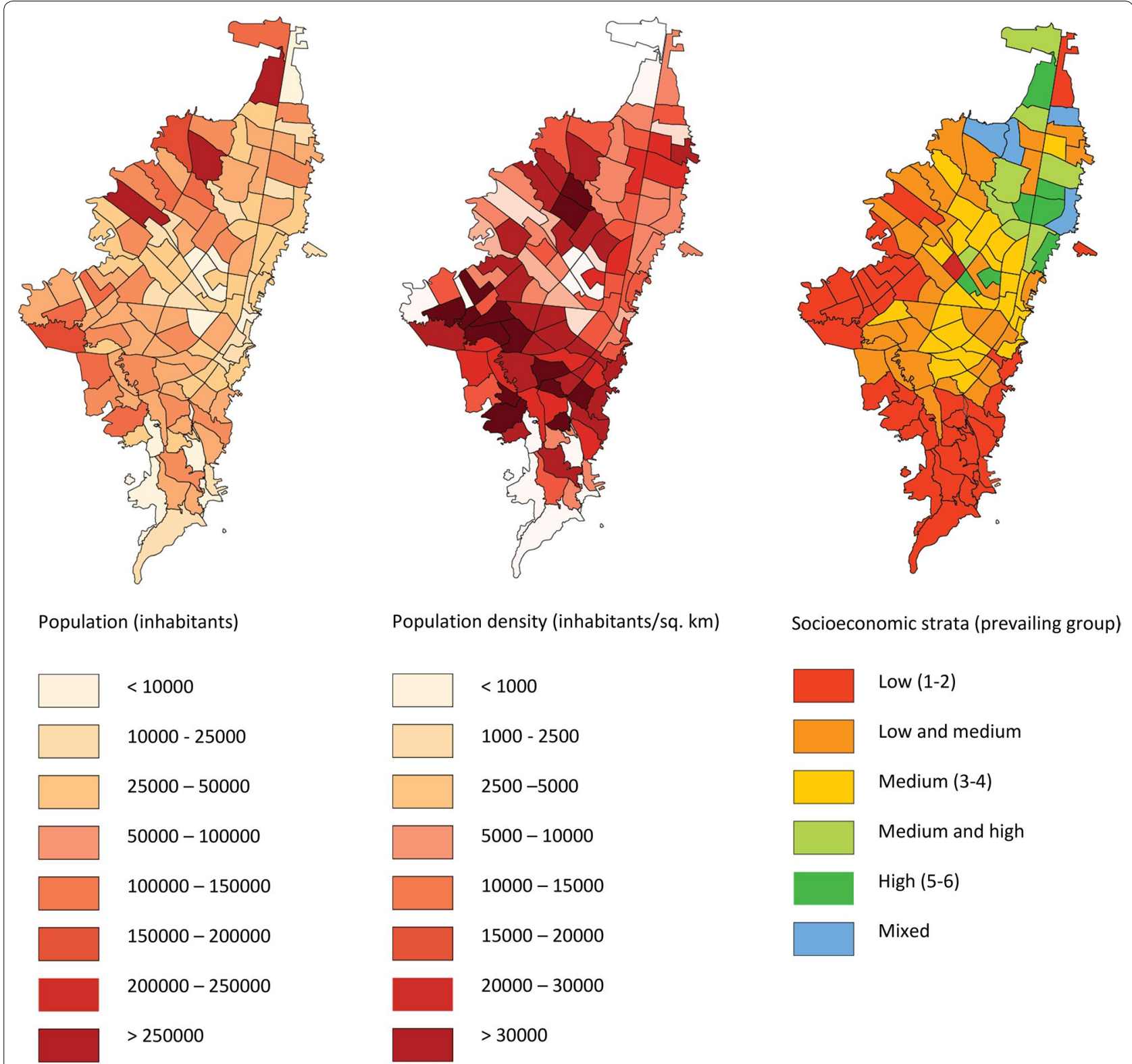

Fig. 1 Population in Bogotá: inhabitants, density and socioeconomic conditions (source: Alcaldía Mayor de Bogotá 2016)

As a city characterized by significant informal settlements and relevant socio-economic disparities, Bogotá does not guarantee equal access to urban opportunities for all its inhabitants. The issues of urban everyday mobility are particularly critical in this sense. For the worst-off strata of the population, public transport is the only modal choice available for medium and longdistance trips (Bocarejo and Oviedo 2012). Moreover, before introducing the celebrated TransMilenio the quality of the public service was quite low, mainly because of the poor institutional arrangements that defined service routes and standards. Transport companies and bus owners were the de facto controllers of the public transport service and were in competition with each other, so that the offered service was slow (the presence of many lines caused congestion), unclear (there was no integration of fares or routes), and uncomfortable (to compete with each other, service providers kept fares low by saving on vehicle maintenance). To provide a solution to Bogotás mobility issues, national and municipal institutions proposed at different times the construction of a subway network, but the proposal is never implemented 


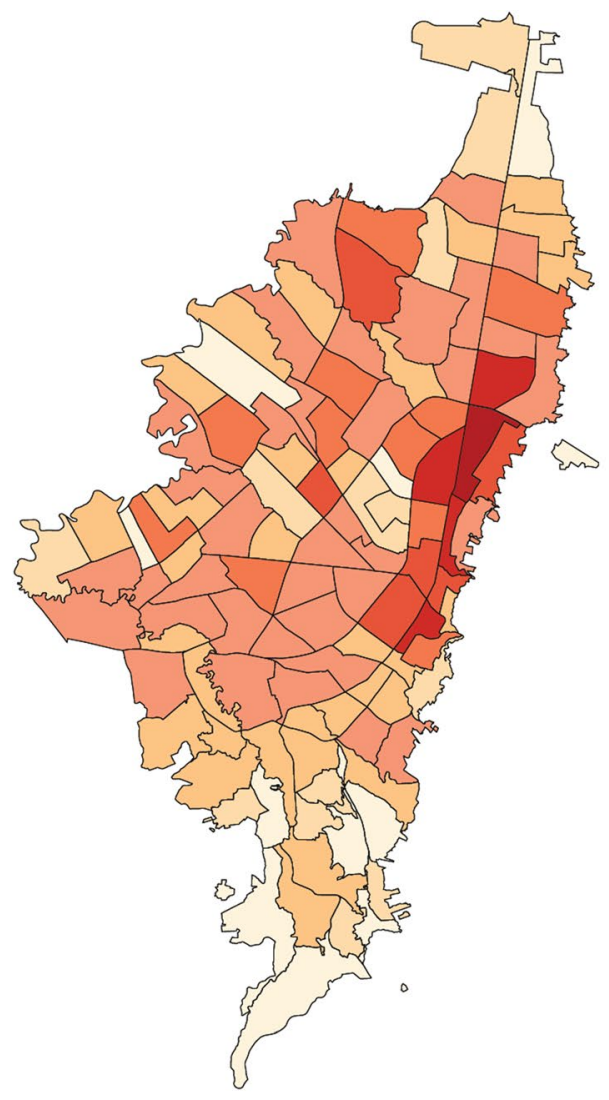

Jobs (formal jobs/UPZ)
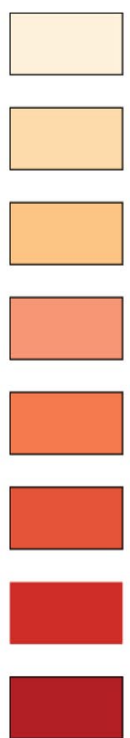

$25000-50000$

$50000-75000$

$75000-100000$

$100000-150000$

$>150000$

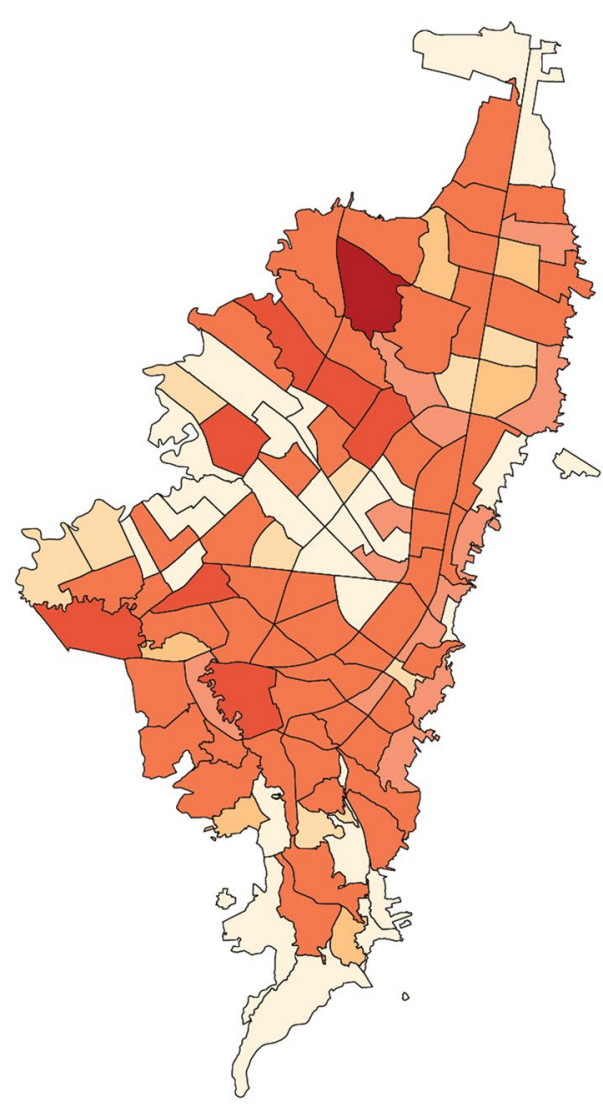

Schools (schools/UPZ)
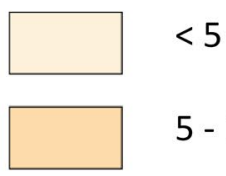

$5-10$

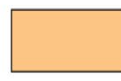

$10-15$

$15-20$

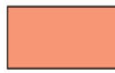

$20-50$

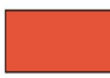

$50-75$

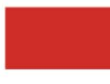

$75-100$

$>100$

Fig. 2 Distribution of jobs and schools in Bogotá (elaboration on Alcaldía Mayor de Bogotá 2011; Dane 2017; Ideca 2017) 
due to lack of funding (see Ardila-Gómez 2004 for a deep reconstruction of transit planning processes in Bogotá).

Bogotá lives a renaissance season in the Nineties thanks to a wave of newly appointed mayors: one of them, Enrique Peñalosa, promotes an alternative approach to the urban mobility issues of the city. Inspired by the similar experience of Curitiba, a middle-size Brazilian city, the mayor proposes the creation of a bus rapid transit system. The project is intended to offer a more reliable public transport service both in the center and in the peripheries, serving different social groups, by requiring lower investments than those for a subway system. Assuming this model, the TransMilenio system is created. The network covers the main road trunks with lanes exclusively reserved to the buses and stops separated by large distances (an average of $500 \mathrm{~m}$, a distance like that inbetween subway stations). The termini of the trunks are intended as interchange poles, where to catch local lines serving peripheral areas. Other elements give an identity to TransMilenio: its red vehicles are quite recognizable, while its evocative name projects Bogotá and its mobility in a new, innovative dimension.

The TransMilenio system has not been fully implemented yet. As of September 2016 (Fig. 3), the network was composed of 12 trunks and was extended for $113 \mathrm{~km}$, with 147 stops; the service had a commercial speed of $26 \mathrm{~km} / \mathrm{h}$, and the daily passengers were approximately 2,4 million (TransMilenio 2016). However, the TransMilenio was not simply intended to improve urban mobility issues. According to the mayor Peñalosa, the TransMilenio was supposed to be "the place where the vice-president of a large corporation or the doorman of a building would feel good. A place where they would meet as equals in an environment that respected human dignity" (Ardila-Gómez 2004, p. 332). In Peñalosa's vision, the construction of the BRT network contributed to a more democratic urban space: "the TransMilenio system built 'democracy' into the urban fabric because the system is citywide and buses are symbols of equality" (Cesafsky 2017, p. 15). The TransMilenio was then conceived not as a modal alternative exclusively for the poor or the rich, but rather as an opportunity for social inclusion, within a wider strategy of urban regeneration. The system intervened on the quality of public transport service, put forward the idea of everyday mobility as a key element for a more democratic access to the city, and contributed to an overall improvement of the image of Bogotá. However, several components determine how TransMilenio contributes to an improved urban access, as the next section explains.

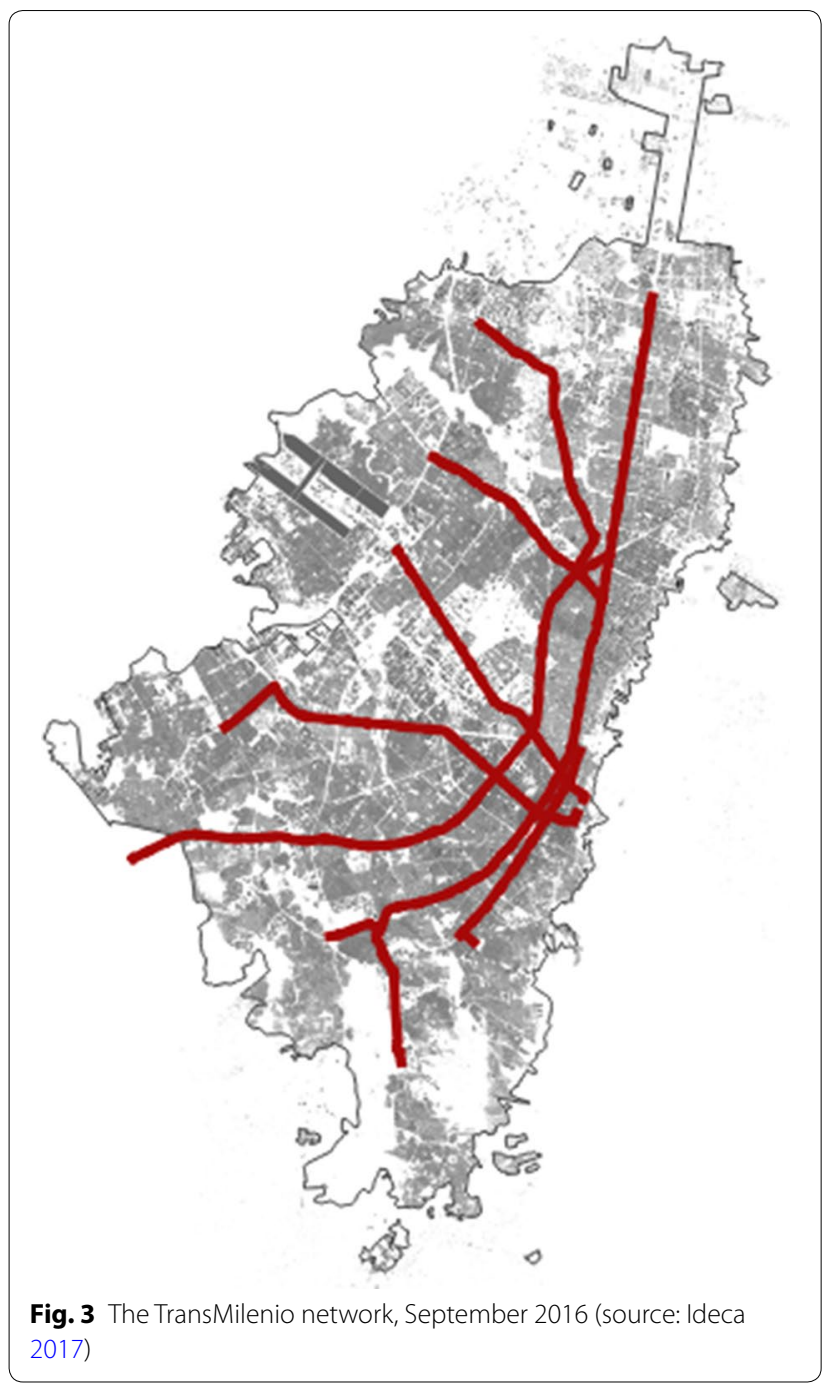

\section{Methodology}

To discuss how the urban transport strategies of Bogotá have contributed or not to improving accessibility to urban opportunities, the paper uses varied sources of information. These data, collected as part of a research project on urban mobility and human capabilities in Bogotá, include a wide range of sources involving both academic and grey literature: statistic and cartographic information from national public bodies of Colombia, municipal institutions of Bogotá and TransMilenio SA, the subject that regulates the public transport system of the city; planning documents, referred to land use and transport strategies; academic research, which provides crucial information for retracing TransMilenio as an urban policy case study as well as earlier evaluations 
of the project; citizens' surveys, which convey how the urban transport system is perceived on a daily basis; and newspapers articles, which discuss current urban mobility projects and issues. The analysis follows a framework that defines how mobility (and mobility systems in particular) allows each person to reach the opportunities that she has reason to value and contributes thus to the personal freedom, considering its significant elements.

Each person has varied opportunities she values, and mobility is required to reach them. In fact, the land use features define "the amount, quality and spatial distribution opportunities supplied at each destination (jobs, shops, health, social and recreational facilities, etc.), the demand for these opportunities at origin locations (e.g. where inhabitants live), and the confrontation of supply of and demand for opportunities, which may result in competition for activities with restricted capacity such as job and school vacancies and hospital beds" (Dijst et al. 2013, pp. 209-210). Each person has different capacities to freely move, depending on personal features as well as on the "possible mobilities according to place, time and other contextual constraints" (Kaufmann et al. 2004, p. 750). Transport systems - and the TransMilenio here discussed-contribute to these possible mobilities. Depending on a personal choice, each person can decide to put into practice such capacity to move, and accessibility to valued opportunities lies amongst its possible uses. Opportunities include a range of resources and activities necessary for the freedom that each individual has to lead one kind of life or another (Nussbaum and Sen 1993) and for the participation to social life. Identifying development with the possibility for everyone to flourish according to what she has reason to value (Nussbaum 2000), individual freedom becomes a social commitment (Sen 1999).

Due to these reflections on people and the society, mobility planning may assume accessibility as its main aim, and transport systems may be evaluated accordingly: transport systems in fact are instrumental for providing the possibility to move required also to access to urban opportunities (Martens 2017). Several aspects enhance or hinder the contribution that transport systems can provide to accessibility; the evaluation of Bogotás TransMilenio will discuss these in the following sections. First, several characteristics define if a transport system is available to a person and contributes thus to her ability to move. The structure of the network defines to which areas and people the system is available, according to the number of neighbourhoods and inhabitants with pedestrian access to the public transport system. Integration instead involves the relationship of the transport system with different built environments and with other transport modes, an aspect which may facilitate or not its use and can be evaluated according to the number of existing interchanges as well as the design of the stations. Regulations instead defines the possibility to enter the transport system, considering in particular the fares and how they impact different socio-economic groups. Then, some aspects influence the actual use of the transport system, referring to the design of its component as well as to the user experience, observable through public evaluations of the service quality. Finally, considering mobility as an instrumental activity required to access opportunities, the places and activities reachable thanks to the examined transport system are considered, as well as the groups to which access is available.

Other elements instead influence the planning decision to implement one specific transport systems or another, and reflect its wider impact on the settings that adopt it. Feasibility for example defines how the desired planning aims can be reached according to the available technical solutions and economic resources. In the case of TransMilenio, the construction costs and the management schemes are discussed, since this economic dimension has been crucial for promoting BRT as a system that achieves at lower expenses the same benefits of other traditional transport systems; a focus on the benefits and costs emerging from traditional forms of appraisal is provided as well. Moreover, the implementation of a transport system may have wider influence on urban transformations, be it directly (for example, through devoted planning initiatives developed around it) or indirectly. Finally, the impact of TransMilenio on urban policy and politics is significant to understand its influence on the strategies of Bogotá as well on the many cities that have replicated it all around the world.

\section{Discussion and evaluation \\ How TransMilenio contributes to the personal ability to move}

The features of TransMilenio influence the possibility that each person has to make use of it, and consequently how the BRT system enhances or hinders the personal ability to move in the city. The relevance of TransMilenio for an improved personal ability to move depends primarily on the areas and the people to which it is available. As for the service area, TransMilenio currently serves a significant part of Bogotá. Assuming that passengers reach the stations by walking and adopting a catchment area of 600 meters (Gutiérrez and García-Palomares 2008), 534 of the 1128 barrios (urban neighborhoods) of Bogotá have walking access to the system. This means that almost 3.7 million inhabitants have access to 
TransMilenio, the $49 \%$ of the total population of the city (Fig. 4). ${ }^{1}$

The evaluation provides a rough estimation of how the BRT system covers the city, but is not much significant in itself. The development of TransMilenio in fact is not complete: the initial plans forecast eight construction phases before reaching the total planned extension of the system, $388 \mathrm{~km}$; right now, only the first three phases have been implemented, while new construction works are ongoing (for example, a contested expansion along the Carrera Septima; see Bogotá Como Vamos 2017). Moreover, since 2012 many ordinary bus lines have been included within an integrated system called Sitp (Sistema Integrado de Transporte Publico), which is intended to formalize existing bus services assuming them as a complementary service to that of TransMilenio. SITP lines and the ordinary bus routes may facilitate the access to the TransMilenio, increasing the number of its potential users, even if difficulties in development and implementation of the integrated system have been experienced (Hidalgo and King 2014; Kash and Hidalgo 2014; Urazán Bonells and Velandia Durán 2012).

TransMilenio is partially integrated to other transport modes, a feature that potentially reduces its effectiveness. Only the portales (i.e. the termini of the trunks) are explicitly designed to have devoted platforms for both the BRT vehicles, both the complementary services that cover the surrounding neighbourhoods. No forms of integration are provided at the intermediate stations, while other public transport services (such as SITP lines, ordinary urban and interurban buses) can be reached only outside the stations. Parking facilities are available just for bicycles and at a very small number of stations ( 15 out of 113; 7 of these are portales). Only the pedestrian access to the stations can thus be considered as significant; as already stated a few years after the opening of TransMilenio, "other access modes to BRT stations, such as by bicycle or car, are either infrequent or irrelevant given there are no integrated facilities for intermodal transfers" (Rodríguez and Targa 2004, p. 596). Finally, the simple design of TransMilenio station is somehow a further element that does not facilitate the integration of the system in the surrounding built environment. Stations are composed of one narrow central platform, of variable length, accessible from one or both the extremities; these can be reached at the ground level or with bridges above the surrounding road carriages. This simple, standardised

\footnotetext{
${ }^{1}$ Elaboration on data from Alcaldía Mayor de Bogotá 2016. It must be noted that official data have limitations in portraying the inhabitants of the informal settlements, so that Bogotá actually hosts more inhabitants than those indicated in official statistics. Consequently, the real percentage of urban population with access to TransMilenio is probably lower than the value here provided.
}

design helps the containment of the construction costs, as well as the insertion of the stops in existing roads without invasive interventions. Nonetheless, it has not been used as the occasion for interventions on public space improving the relationship of the stations with the surrounding neighbourhoods; moreover, the design proves problematic in terms of performances, since it is prone to fast crowding. However, more performant stations designs prove problematic as for their insertion within consolidated built environments, due to the limited available space that in some planned interventions requires the destruction of existing buildings.

The availability of the service provided by TransMilenio also depends on its costs for the passengers, that is, on its fares. Supposedly, the fare system is intended to help the worst-off inhabitants in two ways (Gilbert 2008): paying a fixed fare, those who undergo shorter travels somehow subsidize the longer trips of the people living in the peripheries; moreover, feeder services to the TransMilenio terminals are free, being charged only if the trunk lines are used, and a new ride is charged less if using another bus within $75 \mathrm{~min}$ since the beginning of the travel. Nonetheless, the fare is the most expensive

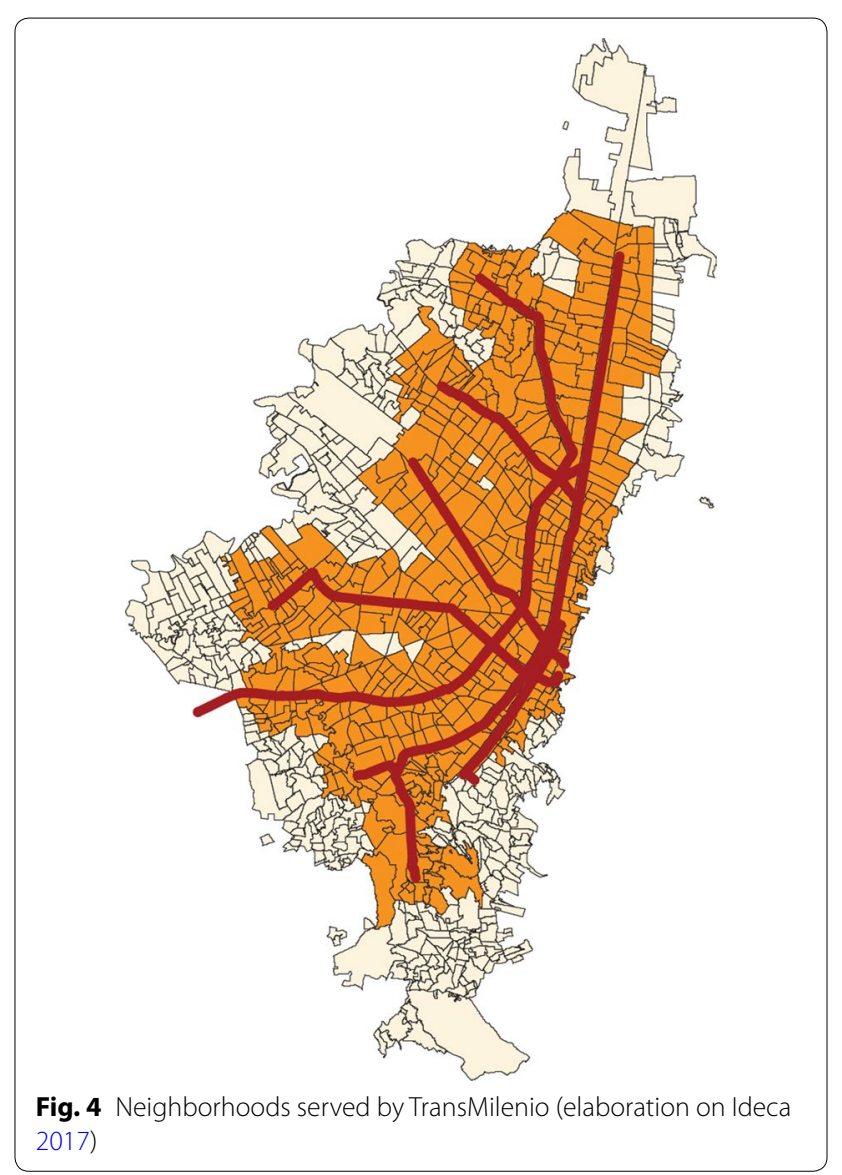


in Colombia and the fourth in all Latin America; furthermore, the integrated public transport system is more expensive than the ordinary buses (with a difference of 650 COP between ordinary buses and TransMilenio) (Espectador 2016). The high prices are responsible for the infrequent use of TransMilenio by low-income groups, even when they have walking access to the system (Teunissen et al. 2015). Moreover, since the beginning of TransMilenio operation, its fares have undergone a yearly average increase of $100 \mathrm{COP}$, and a recent fare increase (introduced in April 2017) has worsened the situation. The prices of the single trips have increased, and their increase has only been partially compensated by a change in the transfer fare. For example, transfers from TransMilenio to Sitp or from Sitp to Sitp are now free, while those moving from a Sitp to a TransMilenio pay 200 COP. Given that the TransMilenio network does not cover effectively the peripheral areas, the fare change mainly affects the low-income users of the public transport system.

The users experience of TransMilenio is a further element that, while depending on the actual use of the system, hinders the possibility to rely on it for future mobility needs. Moving from Mayor Peñalosa's intention to build a system where all the citizens would meet as equals (Ardila-Gómez 2004, p. 332), the system has been designed to provide high-quality services, intending everyday mobility as a fundamental feature to improve "the feeling of connectedness to place and society" (te Brömmelstroet et al. 2017, p. 2). The system has introduced new bi-articulated buses that have higher capacities, as well as reserved seats for disabled people, elderly, or pregnant women. However, the service has experienced a fast decrease in its quality: the huge number of passengers using TransMilenio has produced issues of congestion and insecurity, while the local services of Sitp suffer from a lack of attractiveness due to low frequencies and delays (Cámara de Comercio de Bogotá 2015, p. 47). These are some of the factors that reduce the attractiveness of the system and, consequently, the probability that it is regarded as a future suitable modal choice.

In synthesis, TransMilenio contributes to the personal ability to move in Bogotá, but its contribution is limited to certain areas and groups of inhabitants. Around half of the urban population has direct walking access to the stations of the system, while other groups of inhabitants need to reach the BRT stations with feeder services; the presence of transfers, as well as the increased economic and temporal costs of the trips, reduce the possibility to make effectively use of TransMilenio. The lack of significant forms of integration with other modal options, such as cars or bicycles, furtherly limits the possibility to access the BRT network. Other features instead reduce the intention or the possibility that wide groups have for using TransMilenio. For example, the decreasing quality of the service has pushed the better-off groups of inhabitants towards other modal choices, such as private vehicles. Instead, low-wage groups experience difficulties in accessing the TransMilenio service also due to its fares, so that the system ends up with a majority of middleclass users (Lotero et al. 2014; Heres et al. 2009; Kash and Hidalgo 2014).

\section{How TransMilenio contributes to access urban opportunities}

As the backbone of urban mobility in Bogotá, TransMilenio is potentially a crucial medium to reach significant urban opportunities, at least for the inhabitants who are able to make use of the BRT system. TransMilenio seems to limitedly improve accessibility to urban opportunities in Bogotá, though. The service provided by TransMilenio has a commercial speed of $26 \mathrm{~km} / \mathrm{h}$, much higher in comparison with the previous $10 \mathrm{~km} / \mathrm{h}$ speed of the ordinary services (Montezuma 2000). The increase in the speed reduces the travel times and, consequently, the temporal costs of access to valued urban opportunities. However, the city suffers from a consolidated imbalance in the distribution of inhabitants and opportunities: while the most densely populated (and poorest) areas of the city are located in the southern part of Bogotá, most of the job opportunities are located in the northern sector of the city, privileging in particular an area along the Carrera Septima-slightly above the historic city center (Gutiérrez 2011; Olarte Bacares 2011). Therefore, the areas with the poorer share of the populations are also those that face higher monetary and temporal costs for their everyday mobility. The unequal distribution of activities and the partial coverage of the TransMilenio network strongly limit the improvements provided by the public transport system.

In absence of interventions on land use and activities distribution, TransMilenio has partially improved the access to valued urban opportunities in Bogotá. An example in this sense is provided by accessibility to job opportunities. TransMilenio has facilitated the probability to access the labour market at least in those areas that have access to the BRT network: in fact, it is possible to observe "the existence of a significant correlation between the presence of the Transmilenio in a specific zone of the city and the effective size of the labour market of the population living or working in that zone" (Olarte Bacares 2011, p. 20). Such improvement may apply also to opportunities related to informal economic activities, even if relevant data in this sense are not available. Nonetheless, a disparity in the distribution of TransMilenio's accessibility improvements should be noted. Examining 
the possibilities people have for getting closer to the jobs they are trained to, it emerges that "whereas the improvement in public transport systems such as the Transmilenio entails enhancements of the accessibility, (...) even if it is an improvement of a public service, it does not benefit all social classes equally. The enhancement of the public transport system seems to benefit more the upper classes than the lower ones" (Olarte Bacares 2011, p. 20).

Existing land use features and the BRT network structure question thus the social effectiveness of TransMilenio, despite the intention of constructing a system that improves the access of the local inhabitants to the urban opportunities they value. With the current system, a reduction of monetary and time costs would still be required to improve the access for the worst-off inhabitants of the city (Bocarejo et al. 2016). However, the introduction of TransMilenio has marked an improvement of mobility also in peripheral areas: for example, in the peripheral areas of Usme and Ciudad Bolivar "the users of TransMilenio assure that travel times have noticeably decreased and, consequently, this allowed them a certain optimization of their income due to the facility of using public transport thanks to the complementarity of articulated and feeder buses of the system" (Hernández Bernal and Beltrán Garzón 2010, p. 116).

\section{How TransMilenio provides a suitable urban transport strategy}

The construction of TransMilenio was the outcome of a long decisional process, in which economic factors and planning issues took a relevant part in the technical and political evaluation of two viable alternatives: a subway network or a BRT system (Ardila-Gómez 2004). The economy of TransMilenio is fundamental to understand the worldwide success of the BRT system and its contribution to urban access, as well as how some current issues referred to the production of the service and their impact of Bogotás inhabitants. Similarly, the consequences of the BRT network-both intended and unintended-on the urban development of Bogotá are significant to understand the wider impact that TransMilenio had over the city.

Originally, the construction of a BRT system was supposed to be complemented by a subway network. The geography of Bogotá, characterized by a widespread development in a high plateau, required an extended network to serve a sizeable portion of the city. Despite an initial intention to build both options, the final decision inclined towards the BRT, due its lower construction costs - the BRT costing 5 million $\$ / \mathrm{km}$ against the 100 million $\$ / \mathrm{km}$ required by the metro, at least according to mayor Peñalosa (Ardila-Gómez 2004, p. 318). The construction of the system was funded by the national government and by the municipality, which took advantage of a good financial situation as well as of the privatization of some municipal companies (Ardila-Gómez 2004, pp. 292-293).

While the low costs of construction promoted the BRT in the first phase, three elements related to the construction and the management of the infrastructures are problematic for its performances and, consequently, its impact on the city and its inhabitants (Gilbert 2015). First, institutions are responsible for providing and maintaining lanes, stations and bus deposits, providing a form of indirect subsidy to the public transport system that increases the cost paid by the public. Second, construction costs grew considerably after the first development phase, slowing the expansion of the system. Third, the current crumbling state of infrastructures and some cases of corruption related to new developments of the system decreased the public appreciation of TransMilenio. The choice of the BRT over the subway reduced the infrastructural costs, but the management of the construction contributed to reduce the economic advantages of the bus option.

The construction and the management of the infrastructure are at the expense of the municipality of Bogotá, while private operators provide the public transport service. TransMilenio S.A., the public agency created to manage the system, defines the bus routes and entrust them to the various operators, who are responsible for the provision and the management of buses and drivers. The profits of the service are collected by a private enterprise that redistributes them among operators $(78 \%$ of the profits), the companies that sell tickets and passes (7.5\%), TransMilenio S.A. (5.5\%) and the enterprise itself (0039\%) (Revista Semana 2012). The system is designed to coordinate the public transport services and at the same time benefit private operators: on the one hand, the centralized route planning avoids the previous competition between operators, which had led to a 'price war' compromising the quality of the service; on the other hand, the redistribution of the profits and the public provision of the infrastructures provide enough economic benefits for the private companies, gaining their support to the implementation of a system whose implementation elsewhere has been strongly opposed by the transit operators. Bogotá promoted a balanced involvement of varied actors, even if the primacy of public or private subjects in the provision of transport services is still debated (PagetSeekins and Tironi 2016; Ardila 2008).

TransMilenio has introduced several improvements in comparison with the previously available public transport system, at lower expenses than other infrastructural options. Some of the improvements have been already mentioned, as for the increased commercial speed and 
the enhanced efficiency of the system (whose buses have higher capacity if compared to traditional vehicles, so that less buses are required for carrying the same number of passengers). These improvements facilitated at least partially the access to urban opportunities, for example reducing the temporal costs of travel. Also traditional economic evaluations such as cost-benefit analyses highlight such positive performances (Carrigan et al. 2013, pp. 49-57). TransMilenio shows a positive present net value and the benefits are higher than the costs (see Tables 1 and 2); the consistent investments required for building the infrastructure and renovating the circulating vehicles

Table 1 TransMilenio CBA Summary Indicators source Carrigan et al. (2013), p. 52

\begin{tabular}{lll}
\hline & COP billion (2012) & USD billion (2012) \\
\hline $\begin{array}{l}\text { Present value 1998-2017 } \\
\text { costs }\end{array}$ & $4239 \$$ & $2359 \$$ \\
$\begin{array}{l}\text { Present value 1998-2017 } \\
\text { benefits }\end{array}$ & $6755 \$$ & $3759 \$$ \\
$\begin{array}{l}1998-2017 \text { benefit/cost ratio } \\
\begin{array}{l}1998-2017 \text { internal rate of } \\
\text { return }\end{array}\end{array}$ & 1.59 & \\
\hline
\end{tabular}

have thus been repaid by the current performances of the system. While several elements that enter the cost-benefit appraisal have not been considered in the previous discussion (for example, the impact on air pollution), the two elements responsible for the most significant gains are strictly related to a better access to urban opportunities: the travel time savings and the savings allowed by the introduction of new buses (which reduced passenger congestion and improved the speed of the service).

Despite the apparently good architecture of the system and its positive ex-post evaluations (Hidalgo et al. 2013), the public transport network of Bogotá is currently affected by two economic issues that strongly reduce its effectiveness: the operators are experiencing serious financial deficits, and the fares are being noticeably increased. The current financial crisis of the operators can be explained by three factors (Marín Correa 2016). First, the implementation of the SITP is not complete, so that the routes of the system are directly in competition with the ordinary, cheaper buses (whose ticket costs 1550 COP against the 2000 COP of the SITP buses and the 2200 COP of TransMilenio routes, as of May 2017). Second, despite continuous increases in the public transport

Table 2 Present value of costs and benefits for phases 1 and 2 of TransMilenio source Carrigan et al. (2013), p.55

\begin{tabular}{|c|c|c|}
\hline & COP billion (2012) & USD billion (2012) \\
\hline \multicolumn{3}{|l|}{ Cost } \\
\hline \multicolumn{3}{|l|}{ Public } \\
\hline Studies and project preparation costs & $28.8 \$$ & $116.03 \$$ \\
\hline Real estate purchase and resettlement & $332.46 \$$ & $3759 \$$ \\
\hline Infrastructure construction and/or rehabilitation & $2014.01 \$$ & $1120.83 \$$ \\
\hline Infrastructure maintenance & $102.8 \$$ & $57.21 \$$ \\
\hline Implementation of control centre & $34.19 \$$ & $19.03 \$$ \\
\hline Control centre operation & $7.53 \$$ & $4.19 \$$ \\
\hline Costs of the public project management agency & $65.21 \$$ & $36.29 \$$ \\
\hline Salvage value & $-743.874 \$$ & $-413.98 \$$ \\
\hline \multicolumn{3}{|l|}{ Private } \\
\hline Bus fleet acquisition & $509.52 \$$ & $283.55 \$$ \\
\hline Bus fleet operation & $878.3 \$$ & $488.79 \$$ \\
\hline Implementation of collection system & $23.08 \$$ & $12.85 \$$ \\
\hline Collection system operation & $243.84 \$$ & $135.7 \$$ \\
\hline \multicolumn{3}{|l|}{ Benefits } \\
\hline Reduced transit travel time & $3,287,721 \$$ & $1830 \$$ \\
\hline Time lost during construction & $(-160,157 \$)$ & $(-89 \$)$ \\
\hline Reduced transit operating cost & $2,503,937 \$$ & $1393 \$$ \\
\hline Fewer accidents & $517,520 \$$ & $288 \$$ \\
\hline Positive health impacts due to lower emissions & $235,068 \$$ & $131 \$$ \\
\hline Physical activity benefits & $177,310 \$$ & $99 \$$ \\
\hline CO2 equivalent emissions avoided & $193,877 \$$ & $108 \$$ \\
\hline Total costs & $4239.75 \$$ & $2359.48 \$$ \\
\hline Total benefits & $6,755,276 \$$ & $3759 \$$ \\
\hline
\end{tabular}


fares, the price of the ticket hardly covers the costs of the service, so that the system does not self-sustain itself and is not financially sustainable. Third, the current regulations do not focus on the quality of the service, questioning the overall possibility to effectively access the system (Pachón Torres 2016). Therefore, public transport operators provide a service of lower quality, without investing in the renewal nor in the regular maintenance of their bus fleet.

TransMilenio has also generated intended and unintended wider urban transformations. The BRT network has provided the occasion for interventions on public equipment, related in particular to mobility and culture (Gouverneur 2016, pp. 129-134). For example, the construction of BRT corridors in existing urban highways has allowed the implementation of both reserved lanes for the bus, both bicycle lanes (called Ciclorutas). The network of bicycle lanes covers also the main road axes where also the TransMilenio service is present, and may provide-at least potentially-a feeder for the BRT network; nonetheless, low-income groups are those with the lowest TransMilenio modal share and the highest cycling modal share (Teunissen et al. 2015), so that the bicycle appears to be not a complementary but rather an alternative option to a public transport service perceived as expensive. Another significant public intervention concerned the construction of public libraries, which took advantage of locations with improved accessibility thanks to the TransMilenio network. Nonetheless, their implementation was not part of a comprehensive planning strategy for the regeneration of specific areas, since the land use plans of Bogotá (POT, Plan de Ordenamiento Territorial) defined a generic vision of sustainable development for the city but did not specifically associated these interventions with the implementation of TransMilenio (Robazza 2005). In this sense, the successful Colombian experience of Medellin and its 'social urbanism' provide a different example: the construction of cableways serving some informal settlements was intended to increase the accessibility to and from these marginal areas, but it was also intended as the backbone for a wider urban regeneration strategy made of material and immaterial actions-such as the requalification of public spaces, the provision of new libraries, the creation of business incubators (Brand and Dávila 2011).

The implementation of TransMilenio has also had relevant unintended impacts on the urban development. For example, the BRT system has significantly influenced the real estate values and the household income of the areas along the BRT corridors, influencing further the social impact of the infrastructure. The BRT system has had a progressively favorable impact on property values, generating economic benefits for both residential and commercial estates (Perdomo Calvo 2017). This process of valorization has been used to justify the implementation of new BRT systems in Colombia, but may generate further negative social consequences. In fact, also household incomes have increased in areas adjacent to TransMilenio stations, a fact that could be explained as the consequence of a relocation process (Heres et al. 2009): wealthier subjects appear to have replaced the previous, poorer inhabitants, a critical element for a public transport initiative supposedly driven by a commitment to the poorest groups of the city.

\section{The policy and politics of TransMilenio}

The impact of TransMilenio is reflected also in the influence it had on urban mobility policy, promoting the replication of a model intended to improve the needs of huge mobility flows in cities and countries characterized by scarce resources. This contribution can be observed at three scales: the municipal dimension, referring to Bogotá; the national dimension, involving Colombia; and the worldwide dimension, including the international promotion and replication of TransMilenio.

As for the municipal scale, the introduction of TransMilenio has had a crucial impact on both urban policy and politics. As for the policy, the implementation of such an extended BRT network provides a specific direction to future developments of urban mobility strategies and does not leave much space for other alternatives: TransMilenio already covers a significant share of everyday trips in the city (Cámara de Comercio de Bogotá 2015, p. 11) and it is just in the Phase 3 of the eight that were originally planned, while the resources required for its maintenance and expansion make difficult to plan other huge interventions. The construction of a subway line, recently relaunched by the same mayor Peñalosa (elected for a new term in 2016), is now presented as a complementary option that will provide faster connections and guarantee that more than the $80 \%$ of Bogotás inhabitants will live no farther than $1 \mathrm{~km}$ from a massive transport line (Alcaldía Mayor de Bogotá 2017). Instead, peripheral settlements should benefit from devoted infrastructure such as cableways that, connecting impervious informal settlements to the closest terminal of massive transport, should reduce travel times for the inhabitants of the peripheries; a strategy imported from the city of Medellin (Dávila 2013), the first Metrocable should serve a small portion of the peripheral locality of Ciudad Bolivar (Guerrero Arciniegas 2016). Despite criticism over the technical evaluations referred to these interventions, it still visible the declared aim to prioritize public transport and use it as a tool to guarantee a wider access to the city for all. In his second term, Mayor Peñalosa is currently using these two projects as one of the main 
initiatives of his government. Being a strategic field for planning (Geissler et al. 2017), mobility continues thus to play a fundamental role in the urban politics of Bogotá, after having boosted the political careers of the mayors involved in the development of TransMilenio; similarly, previous mayors have had their careers ended due to corruption scandals involving maintenance and expansion of public transport infrastructures (Gilbert 2015), something that may affect Peñalosa himself (Carrillo 2016).

At the national level, the public transport strategies of Bogotá have had a major influence, leading to the adoption of national legislation for the promotion of bus rapid transit systems in all the main cities of Colombia. The spreading of BRT in other Colombian cities has been promoted using evidences of improved economic performances thanks to TransMilenio (World Bank 2002), as well as with devoted funds provided by the national government. It should be noted however that the same technical solution was replicated in settings quite different from Bogotá, in terms of spatial features, socioeconomic conditions, and existing transport systems, leading to ambiguous results. It is demonstrated by Cali, the third city of Colombia: its public transport system proves to only partially provide enough access to the city (Jaramillo et al. 2012), is quite criticized due to its service (Delmelle and Casas 2012; Casas and Delmelle 2014) and has also been affected by cases of corruption. The Colombian setting proves thus that the simple replication of a successful public transport strategy is not enough to guarantee positive results elsewhere, especially in terms of social impact: in many cases, significant imbalances still exist between the access opportunities available to different strata of the urban population, so that to reach their destinations "the rich still don't have to rise early" (Lotero et al. 2016).

Finally, the TransMilenio has had a huge worldwide impact. It has been the main element used to demonstrate the new course of Bogotá, promoting its regeneration as a model for the main Global South metropolises striving to improve the quality of their urban life. More importantly, the BRT has become one leading reference for public transport strategies in developing countries (United Nations Human Settlements Programme 2013). Its success does not rely only on the technical relevance of the project, but also on its social and political meaning: TransMilenio is a 'Southern innovation' that intercepts the wider aspirations, ideologies and positioning of other cities in the Global South (Wood 2015). Though inspired on the experience of Curitiba, Bogotá could replicate on a wider scale the implementation of a BRT system, becoming thus a reference for many other cities from Latin America, Asia and Africa. Nonetheless, even at a global scale the promotion of a feasible technical solution to achieve desired sociopolitical aims has been partially successful, as numerous examples-even positive onesdemonstrate (Oviedo Hernandez and Joshi 2016).

\section{Conclusions}

The case of Bogotá demonstrates how new urban mobility infrastructures can improve the overall access to urban opportunities, even if their contribution alone is not sufficient. Bogotá uses TransMilenio as a tool to intervene in a dense and disordered city where no previous massive investments in transport had been promoted, as well as to guarantee an improved access to the city and its opportunities. A lighter infrastructure in comparison to other systems, the bus rapid transit proves to be a valuable solution to provide a wide improvement of the everyday mobility in a setting characterized by scarcity of financial resources. However, almost two decades after its introduction TransMilenio still proves to benefit only a share of Bogotá and its population.

To improve and expand the TransMilenio, a further attention to the issues of access is required. While relevant is the alternative form of intervention promoted by the BRT system, as well as its courage in addressing the apparently untamable mobility of a metropolis like Bogotá, similar strategies should pay more attention to the possibility to make use of this public transport system and to the urban opportunities it allows to reach. TransMilenio does not directly serve the marginal areas of the city, especially in the Southern part of Bogotá; feeder services reaching the BRT stations only partially address this issue, since low frequencies and long travel times dramatically reduce their attractiveness. Moreover, the current fare system strongly impacts on the monthly expenditures of the worst-off families, preventing them from systematically using TransMilenio. However, an extensive expansion of the BRT system is not feasible, due the impervious conditions of the marginal, informal settlements in the periphery of Bogotá as well as to the financial costs of constructing and managing such a wide network. The construction of massive infrastructures does not appear thus to be enough to address the issues of the everyday urban access.

Focusing on access, the case of Bogotá suggests that massive interventions on public transport infrastructures need to be complemented by other planning measures. In general, the recovery of existing and unused infrastructures may complement the construction from scratch of new networks (Barco et al. 2015), while active modes of transport may be promoted in central and intermediate areas of the city for trips covering short and medium distances. Interventions in peripheral areas are more difficult, though. While new infrastructures and services are promoted to access more easily the massive public 
transport network, the costs of travelling-especially monetary ones-still strongly impact the travel decisions of those who live in the peripheries (Bocarejo et al. 2016). Having access in mind, a reverse approach could then be significant: valued opportunities, such as jobs, shops and services, may be brought to the areas that currently have difficulties in accessing them. This attitude would focus on what may be defined as 'immotility', valuing the local dimension and meaning thus stillness as social capital (Ferreira et al. 2017). The limited effectiveness of Bogotá's TransMilenio in guaranteeing access to the city suggests thus that it is not possible to indifferently replicate the same urban mobility strategies on the whole territory of a metropolis. Rather, articulated, place-based strategies are required to improve urban access according to peculiar local needs and opportunities.

In conclusion, Bogotá still appears as "an archipelago without sea" (Leon Borja 2015, p. 17): the various areas of the city have different abilities to access other neighborhoods and the urban opportunities they offer. The implementation of TransMilenio has improved the conditions of Bogotá, in two senses. On the one hand, the BRT system has demonstrated the possibility to intervene on the mobility of a chaotic Urban South metropolis, even with relatively few financial resources. On the other hand, the everyday mobility of the city has improved, but mainly middle-class inhabitants have benefitted from such ameliorations. However, the relevance of TransMilenio is limited if considering that access to significant urban opportunities is still critical, especially when examining peripheral settlements and the worst-off inhabitants. To provide a more democratic access to the city, as TransMilenio was initially intended to do, a focus on urban accessibility and the implementation of measures other than massive infrastructures are required, in Bogotá and anywhere else.

\section{Abbreviations \\ BRT: bus rapid transit; COP: Colombian Pesos; SITP: Sistema Integrado de Transporte Publico.}

\begin{abstract}
Acknowledgements
The author acknowledges Liliana Giraldo Arias for her previous reading of the paper, as well as the anonymous reviewers, whose comments helped improve considerably the final version of the paper.
\end{abstract}

\section{Competing interests}

The author declares that he has no competing interests.

\section{Availability of data and materials}

Data available upon request.

\section{Consent for publication}

Not applicable.

Ethics approval and consent to participate Not applicable.
Funding

Not applicable.

\section{Publisher's Note}

Springer Nature remains neutral with regard to jurisdictional claims in published maps and institutional affiliations.

Received: 1 June 2017 Accepted: 11 October 2017

Published online: 16 October 2017

\section{References}

Alcaldía Mayor de Bogotá (2011) Encuesta de Movilidad de Bogotá 2011, Bogotá

Alcaldía Mayor de Bogotá (2016) Población de Bogotá D.C. y sus localidades, Bogotá. http://www.sdp.gov.co/portal/page/portal/PortalSDP/InformacionTomaDecisiones/Estadisticas/ProyeccionPoblacion:ProyeccionesdeP oblaci\%F3n

Alcaldía Mayor de Bogotá (2017) El metro de Bogotá. http://es.presidencia. gov.co/Documents/MetroRuedaPrensa2016917.pdf\#search=transmile nio80\%25. Accessed 17 May 2017

Ardila A (2008) Limitation of competition in and for the public transportation market in developing Countries: lessons from Latin American Cities. Transp Res Rec J Transport Res Board 2048:8-15

Ardila-Gómez A (2004) Transit planning in Curitiba and Bogotá. Roles in interaction, risk, and change. Massachusetts Institute of Technology, Cambridge

Arsenio E, Martens K, Di Ciommo F (2016) Sustainable urban mobility plans: bridging climate change and equity targets? Res Transp Econ 55(May):30-39

Ballvé T (2012) Everyday state formation: territory, decentralization, and the narco landgrab in Colombia. Environ Plan D Soc Space 30: 603-622. http://journals.sagepub.com/doi/pdf/10.1068/d4611. Accessed 16 May 2017

Barco D, Pinilla C, Tarchopoulos D (eds) (2015) Bogotá: urban interactions and future mobility. Pontificia Universidad Javeríana, Bogotá

Beyazit E (2011) Evaluating social justice in transport: lessons to be learned from the capability approach. Transp Rev 31(1):117-134

Bocarejo JP et al. (2016) Accessibility analysis of the integrated transit system of Bogotá. Int J Sustain Transp 10(4): 308-320. http://dx.doi.org.ezproxy. uniandes.edu.co:8080/10.1080/15568318.2014.926435

Bocarejo JP, Oviedo D (2012) Transport accessibility and social inequities: a tool for identification of mobility needs and evaluation of transport investments. J Transp Geogr 24:142-154

Bogotá Como Vamos (2017) Proyecto: Construyendo nuestra Séptima. http:// www.bogotacomovamos.org/proyectos/construyendo-nuestra-septima/. Accessed 17 May 2017

Booth D, Hanmer L, Lovell E (2000) Poverty and transport. Overseas Development Institute, London

Brand P, Dávila JD (2011) Mobility innovation at the urban margins. City 15(6):647-661

Cámara de Comercio de Bogotá (2015) Observatorio de Movilidad. Reporte Anual de Movilidad 2014. Universidad de los Andes, Bogotá

Carrigan A et al. (2013) Social, environmental and economic impacts of BRT systems. Bus rapid transit case studies from around the World. http://www.wrirosscities.org/research/publication/ social-environmental-and-economic-impacts-bus-rapid-transit

Carrillo C (2016) Peñalosa y su trancón de intereses. Al Garete. http://www. algarete.com.co/penalosa-y-su-trancon-de-intereses/

Casas I, Delmelle EC (2014) Identifying dimensions of exclusion from a BRT system in a developing country: a content analysis approach. J Transp Geogr 39:228-237. doi:10.1016/j.jtrangeo.2014.07.013

Cass N, Shove E, Urry J (2005) Social exclusion, mobility and access. Sociol Rev 53(3):539-555

Cesafsky L (2017) How to mend a fragmented City: a critique of "Infrastructural Solidarity." Int J Urban Reg Res. http://doi.wiley.com/10.1111/14682427.12447. Accessed 30 May 2017 
Cresswell T (2010) Towards a politics of mobility. Environ plan D Soc Space 28(1):17-31

Dane (2017). Gran Encuesta Integrada de Hogares, Bogotá. https://www. dane.gov.co/index.php/estadisticas-por-tema/mercado-laboral/ empleo-y-desempleo/geih-historicos

Dávila JD (ed) (2013) Urban mobility and poverty. Lessons from Medellín and Soacha. DPU, UCL and Universidad Nacional de Colombia, Bogotá

Delmelle EC, Casas I (2012) Evaluating the spatial equity of bus rapid transitbased accessibility patterns in a developing country: the case of Cali, Colombia. Transp Policy 20:36-46

Dijst M, Rietveld P, Steg L (2013) Individual needs, opportunities and travel behaviour: amultidisciplinary perspective based on psychology, economics and geography. In: van Wee B, Annema JA, Banister D (eds) The transport system and transport policy. Elgar, Celtenham

Doughty K, Murray L (2016) Discourses of mobility: institutions, everyday lives and embodiment. Mobilities 11 (2): 303-322. http://www.tandfonline. com/doi/pdf/10.1080/17450101.2014.941257. Accessed 4 May 2017

Espectador 2016 Nueva tarifa en pasaje de TransMilenio, dentro de las más costosas de Latinoamérica. El Espectador. http://www.elespectador.com/ noticias/bogota/nueva-tarifa-pasaje-de-transmilenio-dentro-de-mascosto-articulo-611928

Ferreira A, Bertolini L, Næss P (2017) Immotility as resilience? A key consideration for transport policy and research. Appl Mobil 2(1): 16-31. https:// www.tandfonline.com/doi/full/10.1080/23800127.2017.1283121. Accessed 18 May 2017

Geissler J-B, Tricarico L, Vecchio G (2017) The Construction of a trading zone as a political strategy: a review of the LondonInfrastructure Plan 2050. Eur J Spat Dev 64:1-22

Gilbert A (2008) Bus rapid transit: is transmilenio a miracle cure? Transp Rev 28(4):439-467

Gilbert A (2015) Urban governance in the South: how did Bogotá lose its shine? Urban Stud 52(4):665-684

Gouverneur D (2016) Diseño de nuevos asentamientos informales. Fondo Editorial Universidad Eafit; Ediciones Unisalle, Medellín

Graham S, Marvin S (2001) Splintering Urbanism. Routledge, Networked infrastructures, technological mobilities and the urban condition, London

Guerrero Arciniegas C (2016) Todo listo para el cable a Ciudad Bolívar. El Espectador. http://www.elespectador.com/noticias/bogota/ todo-listo-el-cable-ciudad-bolivar-articulo-643590

Gutiérrez D (2011) Determinantes de la localización del empleo urbano en Bogotá, Colombia. Revista de Economía del Rosario 14(1):61-98

Gutiérrez J, García-Palomares JC (2008) Distance-measure impacts on the calculation of transport service areas using GIS. Environ Plan B Plan Des 35(3):480-503

Heres DR, Darby J, Salon D (2009) Do public transport investments promote urban economic development? Evidence from bus rapid transit in Bogotá, Colombia. Transportation 41:57-74

Hernández Bernal JA, Beltrán Garzón JG (2010) Análisis e incidencia del gasto en transporte público de los hogares en las localidades de Usme y Ciudad Bolívar. Equidad \& desarrollo 13:99-117

Hidalgo D, King R (2014) Public transport integration in Bogotá and Cali, Colombia-facing transition from semi-deregulated services to full regulation citywide. Res Transp Econ 48:166-175. doi:10.1016/j. retrec.2014.09.039

Hidalgo D et al (2013) TransMilenio BRT system in Bogotá, high performance and positive impact-Main results of an ex-post evaluation. Res Transp Econ 39(1):133-138. doi:10.1016/.jetrec.2012.06.005

Ideca (2017) Portal de mapas de Bogotá. http://mapas.bogota.gov.co/. Accessed 17 May 2017

Jaramillo C, Lizárraga C, Grindlay AL (2012) Spatial disparity in transport social needs and public transport provision in Santiago de Cali (Colombia). J Transp Geogr 24:340-357. doi:10.1016/j.jtrangeo.2012.04.014

Kash G, Hidalgo D (2014) The promise and challenges of integrating public transportation in Bogotá, Colombia. Public Transp 6: 107-135. http://link. springer.com/10.1007/s12469-013-0083-7

Kaufmann V, Bergmann MM, Joye D (2004) Motility: mobility as Capital. Int J Urban Reg Res 28(4):745-756

Kellerman A (2012). Potential Mobilities. Mobilities 7(1): 171-183. http://www. tandfonline.com/loi/rmob20\%5Cnhttp://dx.doi.org/10.1080/17450101.20 12.631817\%5Cnhttp://www.tandfonline.com/
Kenyon S, Lyons G, Rafferty J (2002) Transport and social exclusion: investigating the possibility of promoting inclusion through virtual mobility. J Transp Geogr 10(3):207-219

Larsen J, Axhausen KW, Urry J (2006) Geographies of social networks: meetings, travel and communications. Mobilities 1(2): 261-283. http://www. informaworld.com/smpp/content $\sim$ content $=\mathrm{a} 748007261 \sim \mathrm{db}=\mathrm{all} \sim$ ord er=page

Leon Borja L (2015) Fachadas bogotanas. Milserifas, Bogotá

Litman T (2010) Evaluating transportation equity guidance for incorporating distributional impacts in transportation planning. Victoria Transport Policy Institute, Victoria

Lopez-Calva LF, Lustig N, Ortiz-Juarez E (2015) A long-term perspective on inequality and human development in Latin America. J Hum Dev Capab 16(3):319-323

Lotero L et al (2014) Socioeconomic differences in urban mobility. In: Garas A (ed) Interconnected networks. Springer, Berlin

Lotero L et al (2016) Rich do not rise early: spatio-temporal patterns in the mobility networks of different socio-economic classes. R Soc Open Sci 3(10):150654

Lucas K (2012) Transport and social exclusion: where are we now? Transp Policy 20: 105-113. http://linkinghub.elsevier.com/retrieve/pii/ S0967070X12000145

Lucas K, Mattioli G et al (2016a) Transport poverty and its adverse social consequences. Proc Inst Civil Eng Transp 169(6):353-365

Lucas K, van Wee B, Maat K (2016b) A method to evaluate equitable accessibility: combining ethical theories and accessibility-based approaches. Transportation 43(3):473-490. doi:10.1007/s11116-015-9585-2

Manaugh K, Badami MG, El-geneidy AM (2015) Integrating social equity into urban transportation planning : a critical evaluation of equity objectives and measures in transportation plans in North America. Transp Policy 37:167-176. doi:10.1016/..tranpol.2014.09.013

Marín Correa A (2016) Los números rojos del SITP. El Espectador. http://www.elespectador.com/noticias/bogota/ los-numeros-rojos-del-sitp-articulo-658198

Martens K (2017) Transport justice: designing fair transportation systems. Routledge, London

Montezuma R (2000) Presente y futuro de la movilidad urbana en Bogotá: Retos y realidades. Veeduría Distrital, Bogotá

Nussbaum MC (2000) Women and human development: the capabilities approach. Cambridge University Press, Cambridge

Nussbaum MC, Sen AK (1993) The quality of life. Clarendon, Oxford

Olarte Bacares CA (2011) Heterogeneity of social classes and job accessibility: implications of transports policies in Bogota. In: 51st ERSA conference, Barcelona

Oviedo Hernandez D, Joshi R (2016) Transport governance of the "International best practice": parallels between BRT developments in Ahmedabad and Bogotá. In: World Conference on Transport Research, Shanghai

Pachón Torres AF (2016) Las concesiones de Transmilenio y Sitp vs los derechos de acceso al transporte público. Ibanez, Bogotá

Paget-SeekinsL, Tironi M (2016) The publicness of public transport: the changing nature of public transport in Latin American cities. Transp Policy 49: 176-183. http://www.sciencedirect.com/science/article/pii/ S0967070X16302256. Accessed 17 May 2017

Perdomo Calvo JA (2017) The effects of the bus rapid transit infrastructure on the property values in Colombia. Travel Behav Soc 6:90-99

Preston J, Rajé F (2007) Accessibility, mobility and transport-related social exclusion. J Transp Geogr 15(3):151-160

Revista Semana (2012). Diez respuestas para entender cómo funciona Transmilenio. Semana. http://www.semana.com/nacion/articulo/ diez-respuestas-para-entender-como-funciona-transmilenio/254946-3

Robazza G (2005) Bogotá DC: una rivoluzione urbana. Area 82:160-181

Robinson JA (2016) La miseria en Colombia. Revista Desarrollo y Sociedad 76: 9-90. doi:10.0.50.243/DYS.76.1\%5Cnhttp://search.ebscohost.com/login. aspx?direct=true\&db=a9h\&AN=113572470\&lang=es\&site=ehost-live

Rodríguez DA, Targa F (2004) Value of accessibility to Bogotá's bus rapid transit system. Transp Rev 24(5):587-610

Salcedo Fidalgo A (2015) Víctimas y trasegares: forjadores de ciudad en Colombia 2002-2005. Universidad Nacional de Colombia, Bogotá

Schwanen T et al (2015) Rethinking the links between social exclusion and transport disadvantage through the lens of social capital. Transp Res Part A 74:123-135. doi:10.1016/j.tra.2015.02.012 
Sen AK (1999) Development as freedom. Oxford University Press, Oxford Stanley J, Vella-Brodrick D (2009) The usefulness of social exclusion to inform social policy in transport. Transp Policy 16(3):90-96. doi:10.1016/j. tranpol.2009.02.003

Székely M, Mendoza P (2015) Is the decline in inequality in Latin America here to stay? J Hum Dev Capab 16(3): 397-419. http://www.tandfonline.com/ doi/full/10.1080/19452829.2015.1050320. Accessed 17 May 2017

te Brömmelstroet M et al. (2017) Travelling together alone and alone together: mobility and potential exposure to diversity. Appl Mobil 2(1): 1-15. https://www.tandfonline.com/doi/full/10.1080/23800127.2017.1283122. 12 Accessed May 2017

Teunissen T et al. (2015) Mapping equality in access: the case of Bogotá's sustainable transportation initiatives. Int J Sustain Transp 9(7): 457-467. doi: 10.1080/15568318.2013.808388. http://search.ebscohost.com/login.aspx? direct $=$ true \&db=a9h\&AN=100935880\&site=ehost-live

Torres Tovar CA (2009) Ciudad informal colombiana. Universidad Nacional de Colombia, Barrios construidos por la gente, Bogotá
TransMilenio (2016) TransMilenio en cifras. http://www.sitp.gov.co/Publicaciones/el_sistema/transmilenio_en_cifras. Accessed 21 Sept 2016

United Nations Human Settlements Programme (2013) Planning and design for sustainable urban mobility. Routledge, Abingdon

Urazán Bonells CF, Velandia Durán EA (2012) Consideraciones sobre el esquema del Sistema Integrado de Transporte Público para Bogotá. Épsilon 18:105-121

Urry J (2007) Mobilities. Polity Press, Cambridge

Wood A (2015) The politics of policy circulation: unpacking the relationship between South African and South American Cities in the adoption of bus rapid transit. Antipode 47(4): 1062-1079. http://doi.wiley.com/10.1111/ anti.12135. Accessed 18 May 2017

World Bank (2002) Cities on the move: World Bank urban transport strategy review. World Bank, Washington

Yiftachel O (2006) Re-engaging planning theory? Towards "South-Eastern" perspectives. Plan Theory 5(3): 211-222. http://plt.sagepub.com/cgi/ doi/10.1177/1473095206068627. Accessed 14 March 2017

\section{Submit your manuscript to a SpringerOpen ${ }^{\circ}$ journal and benefit from:}

- Convenient online submission

- Rigorous peer review

- Open access: articles freely available online

- High visibility within the field

Retaining the copyright to your article

Submit your next manuscript at $\gg$ springeropen.com 